\title{
Pentingnya Mahasiswa Dalam Menjaga Persatuan Dan Kesatuan Di Lingkungan Kampus Maupun Masyarakat
}

\author{
Yoga Fitra Ananta \\ Institut Ilmu Kesehatan STRADA Indonesia \\ yogaananta046@gmail.com
}

\begin{abstract}
Abstrak
Persatuan dan kesatuan merupakan kunci suatu negara dalam membangun suatu bangsa, tanpa adanya rasa tanggung jawab dan kesadaran dalam menjaga persatuan bangsa maka keadaan suatu negara mudah tergoyah oleh berbagai ancaman baik dari luar negeri maupun dalam negeri. Sebagai seorang mahsaiswa yang merupakan generasi penerus bangsa, kita harus memiliki rasa tanggung jawab dan kesadaran dalam menjaga persatuan dan kesatuan untuk memerangi segala ancaman yang mungkin dapat terjadi. Mengingat luas dan mendalamnya kerawanan di negara kita, maka kita harus berkomitmen untuk mengatasi kerawanan-kerawanan tersebut agar tidak muncul lebih besar kepermukaan yang dapat membahayakan persatuan dan kesatuan bangsa.
\end{abstract}

Kata kunci : Persatuan, Kesatuan, Mahasiswa, Ancaman

\section{Latar Belakang}

Indonesia dan negara adi daya seperti Amerika Serikat kerap menjadi sasaran ancaman teroris. Dengan demikian, tampaknya tidak ada di dunia ini suatu negara yang betul-betul aman dari segala ancaman, termasuk bebas dari ancaman terorisme. Amerika Serikat dan negara besar lainnya seperti Perancis justru kerap menjadi sasaran terorisme. Terorisme terjadi lintas negara, melibatkan jaringan yang amat besar serta jenis aksi terror yang satu ini sangat sulit dicegah, bahkan memasuki wilayah kampus. Di Indonesia sendiri paham radikal telah masuk ke berbagai kampus. Pihak kampus harus bisa mendeteksi dan mencegah jika ada kegiatan-kegiatan yang mengarah ke radikal, jika ada indikasi atau gejala semacam itu, harus cepat dilaporkan ke aparat berwenang. Untuk itu semua perlu waspada apalagi sebagai warganegara Indonesia sangat diperlukan kewaspadaan nasional dan ataupun kewaspadaan dini.

Bangsa Indonesia dikenal sebagai bangsa majemuk, ditandai dengan banyaknya etnis, suku, agama, budaya, kebiasaan, di dalamnya.
Di sisi lain, masyarakat Indonesia dikenal sebagai masyarakat multikultural, masyarakat yang anggotanya memiliki latar belakang budaya (cultural background) beragam. Kemajemukan dan multikulturalitas mengisyaratkan adanya perbedaan.

Mahasiswa dapat dikatakan sebagai gabungan dari berbagai macam kelompok, suku, agama dan lain sebagainya. Untuk mencapai kehidupan dalam suatu lembaga perguruan tinggi perlu adanya kerjasama dan kerukunan antar mahasiswa. Namun didalam lembaga perguruan tinggi dibutuhkannya peran mahasiswa dalam membina kerukunan antar mahasiswa supaya terwujudnya kehidupan yang harmonis dan rukun. Sehingga akan menciptakan suasana rukun dan harmonis. Dalam mencapai itu semua tidak lepas dari kehadiran pemimpin dalam suatu lembaga kemahasiswaan namun juga mahasiswa itu sendiri. Membina kedamaian dengan mahasiswa harus atau perlu diawali dengan meningkatkan kerukunan dalam kelompok sendiri bahkan sebaiknya dimulai dari diri sendiri. 
Dasar budaya "Bhinneka Tunggal Ika" merupakan suatu unsur yang sangat fundamental yang dapat dijadikan bingkai dasar untuk merajut kembali goyahnya jati diri kebudayaan bangsa. Kemudian memahami kembali nilai-nilai kearifan lokal yang tergeser pengaruh dari luar untuk mencari makna keIndonesia-an yang sebenar-benarnya dalam arti yang lebih luas sebagai pedoman hidup individu, bermasyarakat, berbangsa dan bernegara.

Dalam kehidupan bermasyarakat yang bertoleransi seperti dijelaskan dalam pancasila sebagai falsafah negara, ideologi negara, landasan dasar dan pandangan hidup bangsa Indonesia, berarti Pancasila merupakan sumber nilai bagi segala penyelenggaraan negara baik yang bersifat kejasmanian maupun kerohanian. Hal tersebut merupakan aspek penyelenggaraan atau kehidupan bernegara yang material maupun spiritual harus sesuai dengan nilai-nilai yang terdapat dalam sila-sila Pancasila secara bulat dan utuh. Karena mahasiswa sadar bahwa didalam kehidupan pada hakekatnya tidak terlepas dari saling ketergantungan antar sesama sehingga mahasiswa selalu berusaha untuk memelihara hubungan yang baik dengan sesamanya.

\section{Kasus/Masalah}

Dalam upaya dalam menjaga persatuan dan kesatuan khususnya dalam lingkungan kampus oleh mahasiswa diperlukan dorongan dan binaan dari diri sendiri yang paling awal. Dengan menemukan kesadaran bahwa dalam kehidupan bersosial harus dapat menyatukan segala perbedaan yang ada. Hal ini disebabkan karena negara kita yang tercinta yaitu Negara Kesatuan Republik Indonesia (NKRI) terdiri dari berbagai macam keberagaman yang ada. Sehingga kita sebagai mahasiswa harus dapat menjunjung tinggi tingkat kesadaran kita dalam persatuan dan kesatuan.

Dalam permasalahan yang mengancam persatuan dan kesatuan rakyat indonesia tidak terlepas pula juga mengancam kalangan mahasiswa. Berbagai ancaman sangat mungkin terjadi dalam lingkungan kampus yang dapat menggoyahkan jiwa persatuan dan ksatuan dari mahasiswa itu sendiri.

Dalam topik kali ini kita akan membahas mengenai pengertian persatuan dan kesatuan. Apa saja ancaman yang mungkin dapat terjadi dalam lingkungan kampus dan bagaimana cara kita dalam menghadapi segala ancaman yang mungkin dapat terjadi tersebut.

\section{Tinjauan Pustaka}

a. Pengertian Persatuan

Persatuan berasal dari kata satu yang artinya tidak terpecah-belah atau utuh. Jadi arti persatuan yaitu bersatunya bermacam-macam aneka ragam kebudayaan menjadi satu yang utuh dan serasi. Persatuan Indonesia adalah persatuan bangsa yang tinggal di wilayah Negara Indonesia, didorong untuk mencapai kehidupan yang bebas dalam negara yang merdeka dan berdaulat. Persatuan bangsa berarti gabungan suku-suku bangsa yang sudah bersatu. Dalam hal ini, masing-masing suku bangsa merupakan kelompok masyarakat yang memiliki ciri-ciri tertentu yang bersatu. Penggabungan dalam persatuan bangsa, masing-masing bangsa tetap memiliki ciri-ciri dan adat istiadat semula. Dalam persatuan bangsa, satu suku bangsa menjadi lebih besar dari sekedar satu suku bangsa yang bersangkutan karena dapat mengatasnamakan bangsa secara keseluruhan. Misalnya suku Bugis atau suku Batak dapat menyebutkan dirinya bangsa Indonesia, yang memiliki ciri jauh lebih luas dan komplek dari pada suku Bugis atau Batak itu sendiri.

\section{b. Pengertian Kesatuan}

Kesatuan adalah ke - Esaan, sifat tunggal atau keseutuhan (WJS. Poerwadarminta). Kesatuan bangsa Indonesia berarti satu bangsa Indonesia dalam satu jiwa bangsa seperti yang diputuskan dalam kongres Pemuda pada tahun 1928 dalam keadaan utuh dan tidak boleh kurang, baik sebagai subyek maupun obyek dalam penyelenggaraan kehidupan nasional. Sedangkan kesatuan wilayah Indonesia berarti satu wilayah Indonesia dari Sabang sampai Merauke yang terdiri dari daratan, perairan dan dirgantara diatasnya seperti yang 
dinyatakan dalam deklarasi Juanda 1957, dalam keadaan utuh dan tidak boleh kurang atau retak.

Indonesia mengandung dua pengertian yaitu, pengertian Indonesia ditinjau dari segi geografis dan dari segi bangsa. Dari segi geografis, Indonesia berarti bagian bumi yang membentang dari $95^{\circ}$ sampai $141^{\circ}$ Bujur Timur dan $6^{\circ}$ Lintang Utara sampai $11^{\circ}$ Lintang Selatan atau wilayah yang terbentang dari Sabang sampai Merauke. Indonesia dalam arti luas adalah seluruh rakyat yang merasa senasib dan sepenanggungan yang bermukim di dalam wilayah itu. Persatuan dan kesatuan bangsa Indonesia berarti persatuan bangsa yang mendiami wilayah Indonesia. Persatuan itu didorong untuk mencapai kehidupan yang bebas dalam wadah negara yang merdeka dan berdaulat.

Persatuan dan kesatuan merupakan senjata yang paling ampuh bagi bangsa Indonesia baik dalam rangka merebut, mempertahankan maupun mengisi kemerdekaan. Persatuan mengandung arti "bersatunya macam-macam corak yang beraneka ragam menjadi satu kebulatan yang utuh dan serasi." Persatuan Indonesia berarti persatuan bangsa yang mendiami wilayah Indonesia. Persatuan dan kesatuan bangsa Indonesia yang kita rasakan saat ini terjadi dalam proses yang dinamis dan berlangsung lama karena persatuan dan kesatuan bangsa terbentuk dari proses yang tumbuh dari unsur-unsur sosial budaya masyarakat Indonesia sendiri, yang ditempa dalam jangkauan waktu yang lama sekali. Unsur-unsur sosial budaya itu antara lain seperti sifat kekeluargaan dan jiwa gotongroyong. Kedua unsur itu merupakan sifat-sifat pokok bangsa Indonesia yang dituntun oleh asas kemanusiaan dan kebudayaan.

Indonesia dalam arti luas adalah seluruh rakyat yang merasa senasib dan sepenanggungan yang bermukim di dalam wilayah itu. Persatuan dan kesatuan Bangsa Indonesia berarti persatuan bangsa yang mendiami wilayah Indonesia. Persatuan itu didorong untuk mencapai kehidupan yang bebas dalam wadah negara yang merdeka dan berdaulat. c. Makna dan Pentingnya Persatuan Dan Kesatuan Bangsa

Kesatuan bangsa Indonesia yang kita rasakan saat ini, itu terjadi dalam proses yang dinamis dan berlangsung lama, karena persatuan dan kesatuan bangsa terbentuk dari proses yang tumbuh dari unsur-unsur sosial budaya masyarakat Indonesia sendiri, yang ditempa dalam jangkauan waktu yang lama sekali.

Unsur-unsur sosial budaya itu antara lain seperti sifat kekeluargaan dan jiwa gotongroyong. Kedua unsur itu merupakan sifat-sifat pokok bangsa Indonesia yang dituntun oleh asas kemanusiaan dan kebudayaan. Karena masuknya kebudayaan dari luar, maka terjadi proses akulturasi (percampuran kebudayaan). Kebudayaan dari luar itu adalah kebudayaan Hindu, Islam, Kristen dan unsur-unsur kebudayaan lain yang beraneka ragam. Semua unsur-unsur kebudayaan dari luar yang masuk diseleksi oleh bangsa Indonesia. Kemudian sifat-sifat lain terlihat dalam setiap pengambilan keputusan yang menyangkut kehidupan bersama yang senantiasa dilakukan dengan jalan musyawarah dan mufakat. Hal itulah yang mendorong terwujudnya persatuan bangsa Indonesia. Jadi makna dan pentingnya persatuan dan kesatuan bangsa dapat mewujudkan sifat kekeluargaan, jiwa gotongroyong, musyawarah dan lain sebagainya.

Tahap-tahap pembinaan persatuan bangsa Indonesia itu yang paling menonjol ialah sebagai berikut: 1 . Perasaan senasib.

2. Kebangkitan Nasional

3. Sumpah Pemuda

\section{Proklamasi Kemerdekaan}

\section{Kesatuan Bangsa}

Hal-hal yang berhubungan dengan arti dan makna persatuan Indonesia apabila dikaji lebih jauh, terdapat beberapa prinsip yang juga harus kita hayati serta kita pahami lalu kita amalkan.

Prinsip-prinsip itu adalah 


\section{Prinsip Bhineka Tunggal Ika}

Prinsip ini mengharuskan kita mengakui bahwa bangsa Indonesia merupakan bangsa yang terdiri dari berbagai suku, bahasa, agama dan adat kebiasaan yang majemuk. Hal ini mewajibkan kita bersatu sebagai bangsa Indonesia.

\section{Prinsip Nasionalisme Indonesia}

Kita mencintai bangsa kita, tidak berarti bahwa kita mengagung-agungkan bangsa kita sendiri. Nasionalisme Indonesia tidak berarti bahwa kita merasa lebih unggul daripada bangsa lain. Kita tidak ingin memaksakan kehendak kita kepada bangsa lain, sebab pandangan semacam ini hanya mencelakakan kita. Selain tidak realistis, sikap seperti itu juga bertentangan dengan sila Ketuhanan Yang Maha Esa dan Kemanusiaan yang adil dan beradab.

3. Prinsip Kebebasan yang Bertanggung jawab

Manusia Indonesia adalah makhluk ciptaan Tuhan Yang Maha Esa. Ia memiliki kebebasan dan tanggung jawab tertentu terhadap dirinya, terhadap sesamanya dan dalam hubungannya dengan Tuhan Yang maha Esa.

\section{Prinsip Wawasan Nusantara}

Dengan wawasan itu, kedudukan manusia Indonesia ditempatkan dalam kerangka kesatuan politik, sosial, budaya, ekonomi, serta pertahanan keamanan. Dengan wawasan itu manusia Indonesia merasa satu, senasib sepenanggungan, sebangsa dan setanah air, serta mempunyai satu tekad dalam mencapai cita-cita pembangunan nasional.

5. Prinsip Persatuan Pembangunan untuk Mewujudkan Cita-cita Reformasi

Dengan semangat persatuan Indonesia kita harus dapat mengisi kemerdekaan serta melanjutkan pembangunan menuju masyarakat yang adil dan makmur.

e. Pengamalan Nilai-nilai Persatuan dan Kesatuan Pengamalan Nilai-nilai Persatuan dan Kesatuan antara lain :
1. Mempertahankan Persatuan dan Kesatuan Wilayah Indonesia. Pepatah mengatakan "bersatu kita teguh, bercerai kita runtuh". Oleh karena itu yang perlu kita tegakkan dan lakukan adalah:

2. meningkatkan semangat kekeluargaan, gotong-royong dan musyawarah; meningkatkan kualitas hidup bangsa Indonesia dalam berbagai aspek kehidupan

3. pembangunan yang merata serta berkeadilan sosial bagi seluruh rakyat Indonesia;

4. memberikan otonomi daerah;

5. memperkuat sendi-sendi hukum nasional serta adanya kepastian hokum

6. perlindungan, jaminan serta menjunjung tinggi hak asasi manusia; dan

7. memperkuat sistem pertahanan dan keamanan sehingga masyarakat merasa terlindungi.

8. Meningkatkan semangat Bhinneka Tunggal Ika.

9. Mengembangkan semangat

kekeluargaan.Yang perlu kita lakukan setiap hari usahakan atau "budayakan saling bertegur sapa."

10. Menghindari penonjolan sara/perbedaan. Karena bangsa Indonesia terdiri dari berbagai macam suku, bahasa, agama serta adat-istiadat kebiasaan yang berbeda-beda, maka kita tidak boleh melakukan perbuatan yang dapat menimbulkan perpecahan. Oleh karena itu yang harus kita hindari antara lain:

1. Egoisme

2. Ekstrimisme

3. Sukuisme

4. Profinsialisme

5. acuh tak acuh tidak peduli terhadap lingkungan

6. fanatisme yang berlebih-lebihan dan lain sebagainya 


\section{e. Cara Mewujudkan Persatuan dan Kesatuan Bangsa}

Untuk dapat memacu diri, agar terbina persatuan dan kesatuan paling kurang terdapat beberapa hal yang perlu dilakukan:

1. berorientasi ke depan dan memiliki perspektif kemajuan;

2. bersikap realistis, menghargai waktu, konsisten, dan sistematik dalam bekerja;

3. bersedia terus belajar untuk menghadapi lingkungan yang selalu berubah;

4. selalu membuat perencanaan;

5. memiliki keyakinan, segala tindakan mesti konsekuensi;

6. menyadari dan menghargai harkat dan pendapat orang lain;

7. rasional dan percaya kepada kemampuan iptek;

8. menjunjung tinggi keadilan; dan

9. berorientasi kepada produktivitas, efektivitas dan efisiensi.

\section{Pembahasan}

Sebagai mahasiswa kita harus mengenal terlebih dahulu apa itu, Persatuan / Kesatuan: Persatuan/kesatuan berasal dari kata satu yang berarti utuh atau tidak terpecah-belah.

Persatuan/kesatuan mengandung arti "bersatunya macam-macam corak yang beraneka ragam menjadi satu kebulatan yang utuh dan serasi”. Menjaga nilai persatuan dan tanggung jawab merupakan hal yang lebih penting meskipun selalu dihadapkan pada perubahan jaman dan tantangan kebutuhan ekonomi. Oleh karena itu, harus ada penjiwaan kuat yang menjadikan suatu tekad dan komitmen bulat seluruh bangsa Indonesia untuk menjaga nilai-nilai persatuan demi kerukunan kehidupan bermasyarakat. Nilai persatuan bukan merupakan fenomena baru, ini telah ada sejak lama, karena keberhasilan suatu pekerjaan disebabkan adanya persatuan, dan hal itu akan berdampak kepada pekerjaan yang lain. Kesatuan bangsa Indonesia yang kita rasakan saat ini, itu terjadi dalam proses yang dinamis dan berlangsung lama, karena persatuan dan kesatuan bangsa terbentuk dari proses yang tumbuh dari unsur-unsur sosial budaya masyarakat Indonesia sendiri, yang ditempa dalam jangkauan waktu yang lama sekali. Unsur-unsur sosial budaya itu antara lain seperti sifat kekeluargaan dan jiwa gotong-royong. Kedua unsur itu merupakan sifat-sifat pokok bangsa Indonesia yang dituntun oleh asas kemanusiaan dan kebudayaan. Karena masuknya kebudayaan dari luar, maka terjadi proses akulturasi (pencampuran kebudayaan). Kebudayaan dari luar itu adalah kebudayaan Hindu, Islam, Kristen dan unsur-unsur kebudayaan lain yang beraneka ragam. Semua unsur-unsur kebudayaan dari luar yang masuk diseleksi oleh bangsa Indonesia. Kemudian sifat-sifat lain terlihat dalam setiap pengambilan keputusan yang menyangkut kehidupan bersama yang senantiasa dilakukan dengan jalan musyawarah dan mufakat. Hal itulah yang mendorong terwujudnya persatuan bangsa Indonesia.

Berbagai dampak yang ditimbulkan oleh kelompok radikal maupun teroris terhadap Negara adalah:

1. Dampak terhadap ideologi. Terorisme sanga bertentangan dengan ideologi Pancasila, yang sangat bertentangan dengan kelima silanya terutama prinsip ketuhanan dan kemanusiaan, karena gerakannya tidak pandang bulu, mengorbankan orang-orang yang tidak bersalah yang tidak tahu apa-apa, dari anakanak, dewasa, orang tua, laki-laki maupun wanita. Dengan di serangnya ideologi tentu akan membuat berantakan rasa persatuan dan kesatuan bangsa;

2. Dampak terhadap agama, terorisme dengan sepihak mengklaim membela saudarasaudara seagamanya, justru mempermalukan agama itu sendiri. Berapa banyak Negara dengan basis mayoritas muslim yang telah dicurigai dunia internasional sebagai sarang teroris. Berapa banyak umat Islam yang dengan ciri tertentu telah dicurigai sebagai teroris. Berapa banyak organisasi Islam yang tidak ada hubungannya dengan kelompok teroris tetapi mendapat kesan yang kurang baik akibat perbuatan teror; 
3. Dampak terhadap politik, beragam aksi teroris baik besar maupun kecil di tanah air telah banyak memberikan dampak politik bagi Indonesia dalam pergaulan internasional. Citra Indonesia sebagai Negara yang tidak aman semakin tidak terhindarkan. Padahal butuh beberapa tahun untuk meyakinkan dunia internasional tentang keamanan dalam negeri yang dalam waktu sekejap diruntuhkan oleh aksi teroris;

4. Dampak terhadap ekonomi, sangat jelas aksi terorisme telah berdampak buruk bagi ekonomi nasional. Tidak hanya bagi persoalan investasi besar yang mulai ragu ketika ada kejadian terorisme, pelaku ekonomi menengah ke bawah yang mengandalkan dunia pariwisata terganggu karena ketidakamanan yang ditimbulkan oleh aksi terorisme;

5. Dampak terhadap kedaulatan dan pertahanan, aksi terorisme yang terjadi seakan ingin menceraikan antara pemerintah dengan warganya. Ketika terorisme terjadi, tidak hanya persoalan keamanan tetapi kedaulatan Negara diusahakan untuk diruntuhkan oleh para teroris dengan cara menanamkan ketidakpercayaan masyarakat terhadap pemerintah.

Demikian masifnya dampak dari terorisme dengan pahamnya yang radikal terhadap Negara dan masyarakat, maka diperlukan kewaspadaan terkait dengan sikap nasionalisme yang terbangun dari rasa peduli dan rasa tanggung jawab seseorang warga Negara terhadap kelangsungan nasionalnya, kehidupan bermasyarakat, berbangsa dan bernegara dari suatu ancaman. Jadi sangat urgen suatu kewaspadaan terhadap ancamanancaman yang bersifat terorisme dan yang berbau radikalisme. Dalam menjaga kesatuan dan persatuan Negara Kesatuan Republik Indonesia (NKRI) maka diperlukan suatu kepedulian terhadap suatu kerawanankerawanan yang dapat mengancam.

Sebagai sebuah negara kesatuan (unitary state), sudah selayaknya dipahami benar makna "kesatuan" tersebut. Dengan memahami secara benar makna kesatuan, diharapkan seluruh komponen bangsa
Indonesia memiliki pandangan, tekat, dan mimpi yang sama untuk terus mempertahankan dan memperkuat kesatuan bangsa dan negara. Filosofi dasar persatuan dan kesatuan bangsa dapat ditemukan pertama kali dalam kitab Sutasoma karya $\mathrm{Mpu}$ Tantular. Dalam kitab itu ada tulisan berbunyi "BhinnekaTunggal Ika tan hana dharma mangrwa", yang berarti "berbeda-beda tetapi tetap satu, tak ada kebenaran yang mendua". Frasa inilah yang kemudian diadopsi sebagai semboyan yang tertera dalam lambing negara Garuda Pancasila.

Ketika sudah dapat memaknai apa itu persatuan dan kesatuan, kita juga harus bisa memahami nilai-nilai yang terdapat dalam sebuah persatuan dan kesatuan. Nilai-nilai itu adalah :

1. Mempertahankan persatuan dan kesatuan wilayah NKRI

2. Meningkatkan semangat Bhinneka Tunggal Ika

3. Mengisi kemerdekaan dengan kegiatan positif

4. Toleransi

5. Menjunjung tinggi Hak Asasi Manusia

6. Menerapkan rasa kekeluargaan

7. Musyawarah dalam setiap pengambilan keputusan

8. Bersikap adil Setiap sesuatu yang berharga pasti punya makna. Persatuan dan kesatuan adalah hal penting yang harus dimiliki setiap bangsa.

Makna pokok tersebut antara lain, yaitu :

1. Menjaga rasa persatuan dan kesatuan dengan menjalin rasa kebersamaan dan saling melengkapi.

2. Menjalin toleransi dan rasa kemanusiaan dengan hidup berdampingan secara harmonis

3. Menjalin rasa

kekeluargaan,persahabatan,saling tolongmenolong, dan rasa nasionalisme. 
Untuk memperkuat persatuan dan kesatuan bangsa terdapat beberapa prinsip yang menjadi pondasinya. Ada 5 prinsip penting, agar lebih jelas kita akan bahas satu persatu dari : (UUD 1945)

\section{Prinsip Bhinneka Tunggal}

Menjiwai arti Bhinneka Tunggal Ika itu sendiri, yang berarti "berbeda-beda tetapi tetap satu jua”. Dengan beragam kebudayaan,ras, dan agama di Indonesia kita diwajibkan bersatu dalam satu bangsa, yaitu bangsa Indonesia.

\section{Prinsip Nasionalisme Indonesia}

Merupakan rasa cinta dan kesetiaan terhadap bangsa Indonesia. Nasionalisme merupakan sikap politik dari masyarakat yang memiliki tujuan dan cita-cita yang sama.

\section{Prinsip Kebebasan yang Bertanggung Jawab}

Maksudnya adalah setiap orang diberi hak untuk memenuhi kemauannya asal tidak menyalahi Hak Asasi Manusia. Jika sampai melanggar dan merugikan orang lain, akan diberikan sanksi berdasarkan perbuatannya.

\section{Prinsip Wawasan Nusantara Wawasan Nusantara}

Dilaksanakan guna memenuhi tujuan nasional. Memiliki fungsi sebagai pedoman, motivasi, dan rambu-rambu dalam menentukan keputusan untuk menyelenggarakan negara.

\section{Prinsip Persatuan Pembangunan untuk Mewujudkan Cita-cita Reformasi}

Sebagai warga negara kita harus bisa mengisi kemerdekaan dengan baik. Caranya dengan melakukan pembangunan dengan dilandasi rasa persatuan. Namun hal tersebut tidak membuat bangsa Indonesia merasa unggul dan menganggap rendah bangsa lain, karena itu dapat menodai sila yang terkandung dalam Pancasila.

Timbulnya kesadaran bertanggung jawab karena manusia hidup bermasyarakat dan hidup dalam lingkungan alam. Manusia tidak boleh berbuat semaunya saja terhadap sesama manusia dan alam lingkungannya. Manusia bertindak sesuai dengan norma kehidupan yang tercermin dalam system nilai budaya mereka, sehingga tercipta

keseimbangan,keserasian, keselarasan antara sesama manusia dan alam lingkungan.

Menjaga persatuan dan kesatuan dalam keberagaman menjadi tanggung jawab seluruh rakyat Indonesia. Persatuan dan kesatuan penting untuk dijaga dan dipertahankan. Sebab, tanpa persatuan dan kesatuan maka akan timbul perpecahan. Dan Tanpa persatuan dan kesatuan tak mungkin Indonesia dapat berdiri seperti sekarang. Oleh karena itu seluruh warga Indonesia wajib menjaga dan bertanggung jawab terhadap persatuan dan kesatuan.

Ancaman serius yang harus dihadapi dan selalu diwaspadai dewasa ini adalah kelompok terorisme, kelompok ini dapat diartikan sebagai tindakan atau ancaman kekerasan dengan tujuan politik tertentu dengan cara menciptakan kepanikan dan ketakutan di tengah-tengah masyarakat dengan sasaran dan target kepada siapa pun dan dimanapun berada yang dilakukan oleh kelompok yang terorganisasi rapi, mempunyai kader militant dengan disiplin tinggi dan jaringan kuat lintas Negara. Oleh karena itu terorisme musuh semua kalangan yang memimpikan dan mencita-citakan perdamaian. Terorisme merupakan musuh Negara yang menyerang kedaulatan Negara dan keamanan masyarakat. Seluruh komponen bangsa harus terpanggil dalam upaya pencegahan terorisme. Terorisme merupakan musuh semua agama karena tidak ada satu pun agama yang mengajarkan kekerasan, kebrutalan. Terorisme tidak berkaitan dengan pemeluk agama tertentu karena dilakukan tidak berdasarkan ajaran agama, karena terorisme itu musuh keamanan dan perdamaian, musuh semua manusia, maka pemberantasan tindak pidana terorisme harus dilakukan secara komprehensif.

Munculnya terorisme oleh kelompok minoritas maupun oleh negara adalah tidak dihargainya nilai-nilai demokrasi maupun nilai-nilai kemanusiaan. Dengan demikian usaha pencegahan terorisme yang efektif adalah usaha untuk menghidupkan dan melaksanakan 
nilai-nilai demokrasi dan nilai-nilai kemanusiaan di masyarakat. Mengantisipasi terorisme yang dilakukan oleh kelompok minoritas relatif mudah, sebab perasaan ketidakpuasan dari kelompok minoritas ini tidak secara serta merta akan diwujudkan dalam bentuk tindakan pemaksaan kehendak. Bila suatu kelompok militan terbentuk, maka sifat ekslusif dari kelompok menjadi menonjol. Kendatipun eksklusifitas belum tentu menghasilkan radikalisme, namun sebagai cikal bakal radikalisme sesungguhnya akan dapat diidentifikasi oleh masyarakat sekitarnya

\section{5. kesimpulan}

Masalah persatuan dan kesatuan bangsa bukan hanya diperlukan pada saat bangsa Indonesia menghadapi kekuasaan asing saja, melainkan terus diperlukan hingga sekarang, agar kemerdekaan bangsa dan negara yang berhasil dicapai oleh para pendahulu kita tidak digoyah dan hancur di tangan kita. Persatuan dan kesatuan menjadi obat penenang keonaran dan kekicruhan kondisi bangsa, sekaligus menjadi harga mati yang harus senantiasa dikedepankan dan dijaga dengan baik Begitu juga dengan nilai moralitas sebagai pembatas dari perbuatan tidak waras.

Sehingga kita sebagai mahasiswa untuk menyadari tentang pentingnya persatuan dan kesatuan dalam lingkungan kampus maupun masyarakat. Dengan ini diharapkan dapat menumbuhkan jiwa persatuan dan kesatuan pada diri mahasiswa untuk menghadapi segala kemungkinan ancaman yang mungkin dapat terjadi di lingkungan kampus.

"Persatuan dan kesatuan yang dibangun bangsa Indonesia bukanlah uniformasi, dan juga bukan untuk meniadakan kemajemukan masyarakat. Karena itu, harus didasari bahwa persatuan dan kesatuan nasional yang kita inginkan adalah persatuan dan kesatuan yang tetap menghargai pluralisme dan sekaligus menghormati dan memelihara keberagaman yang dimiliki bangsa Indonesia. Atau, dengan kata lain, kita tetap menginginkan adanya Bhinneka Tunggal Ika," Dan kemajemukan masyarakat bukanlah merupakan hambatan atau kendala bagi penguatan persatuan dan kesatuan bangsa, bahkan kemajemukan merupakan potensi dan kekuatan yang amat kaya untuk memajukan bangsa dan negara.

\section{Daftar Pustaka}

Awan, I., \& Sodik, M. A. (2018). Diskriminasi dan Kesehatan Mental.

Honggu, N. N. (2021). Persatuan Dan Kesatuan.

Setiabudhi, I. K. R., Artha, I. G., \& Putra, I. P. R. A. (2018). Urgensi Kewaspadaan Dini dalam Rangka Memperkuat Persatuan dan Kesatuan Bangsa. Jurnal Magister Hukum Udayana (Udayana Master Law Journal), 7(2), 250-266.

Repelita, T., Sofyan, F. S., \& Susanto, E. (2021). PERENCANAAN PEMBELAJARAN PENDIDIKAN PANCASILA DALAM UPAYA MENGUATKAN RASA PERSATUAN DAN KESATUAN INDONESIA PADA MAHASISWA DALAM KONSEP MASYARAKAT YANG MULTIKULTUR. PROSIDING KONFERENSI NASIONAL PENELITIAN DAN PENGABDIAN UNIVERSITAS BUANA PERJUANGAN KARAWANG, 1(1), 581-587.

Makna, B. A. Pengertian Persatuan dan Kesatuan Bangsa. 